M. Souza-Silva, A.S. Júnior, and R.L. Ferreira - Food resource availability in a quartzite cave in the Brazilian montane Atlantic Forest. Journal of Cave and Karst Studies, v. 75, no. 3, p. 177-188. DOI: 10.4311/2010JCKS0158

\title{
FOOD RESOURCE AVAILABILITY IN A QUARTZITE CAVE IN THE BRAZILIAN MONTANE ATLANTIC FOREST
}

\author{
Marconi Souza-Silva', Afonso Sálvio Júnior², and Rodrigo Lopes Ferreiraª
}

\begin{abstract}
The litter produced in the exokarst and imported into a quartzite cave were measured, as well as the latter's availability and consumption in aquatic and terrestrial cave habitats. In the exokarst, the litter production increases during the rainy season, although the actual importation of this coarse particulate organic matter into the cave is mainly due to the wind. The sandstone soil and the percolation of water through the epikarst have a filtering effect, and the CPOM input into deeper zones in the cave is limited, despite the presence of a stream. In the terrestrial environment of the cave, percolating water increases plant detritus consumption somewhat during the rainy season, although it is still low, due to the generally dry soil conditions in the cave. The cave can be characterized as an oligotrophic system, especially in the deeper zones, with most invertebrate species occurring near the cave entrances, where the CPOM is more abundant. The forest promotes the presence of trogloxene taxa (opiliones: Goniossoma sp. and Araneae: Enoploctenus sp). Guano in the deeper zones of the cave is extremely scarce and old, so its importance as a basic resource for the cave fauna is quite limited. Conversely, termite colonies and scarce roots recruit trophic resources for the troglophile and troglobite species in the deeper zones. Several cave species were observed in these areas, apparently feeding on roots and the debris left by termites.
\end{abstract}

\section{INTRODUCTION}

Like soils below the litter zone, lakes, and estuaries, caves are primarily heterotrophic systems (Boling Jr. et al., 1975). The absence of light excludes primary photosynthetic producers, although bacterial chemotrophism is the basis of the primary production in some caves (Sarbu et al., 1996; Hose et al., 2000; Chivian et al., 2008). Food resources are thus generally secondary; they are brought into the subterranean environment by rivers or other water sources, whether by slow percolation through fissures in the ceiling or walls or by racing torrents arising during periodic flooding of streams (Simon et al., 2007). Roots can grow through fissures into the conduits of the cave, and animals in transit in the caves, especially bats, can also transport food resources, thus making them available for other inhabitants (Jasinska et al., 1996; Ferreira, 2005, Souza-Silva et al 2011). Above the caves, the availability of organic matter can be influenced by seasonal variation in production rates, hydrological events, or both. The activity of the fauna and the speed of detritus consumption are also dependent on abiotic factors, especially temperature and humidity (Jordan, 1985).

Food webs based on living plants constitute a high proportion of global biodiversity (Hooper et al., 2000), whereas the invertebrate cave fauna is assumed to be less complex, with a smaller number of species exploring the generally limited resources. These trophic webs are thus considered to be simpler than those on the surface (Culver, 1982). However, in caves where food is abundant, the system can be more complex (Jasinska et al., 1996; Ferreira and Martins, 1998; Ferreira and Martins, 1999; Ferreira et al, 2000, 2007, Souza-Silva et al 2011).
For decades ecologists have focused their studies on interactions between and among elements in the same system, with less emphasis given to elements found in border environments (Boling Jr. et al., 1975). Recent studies, however, have focused on the detritus transfer between ecological systems, as well as the consequences to the community structure on different spatial and temporal scales (Graening, 2000; Rodriguez, 2000; Simon et al., 2007; Hills et al., 2008; Schneider et al., 2011; Souza-Silva et al., 2011; Souza-Silva et al., 2012; Venarsky et al., 2012).

Almost all the information available concerning Brazilian cave fauna is directly related to carbonatic systems. It is thus extremely important to understand the primary relations between exokarstic and endokarstic compartments in non-carbonatic systems, especially the trophic processes involved in the dynamics of the exokarst and the caves.

This study was designed to evaluate the trophic ecology in a quartzite cave and its vicinity, including the surface production, transport to the cave, and consumption of coarse particulate organic matter. The invertebrate community present in these caves was also evaluated.

\footnotetext{
${ }^{1}$ Núcleo de Pesquisa em Ciências Biológicas do Centro Universitário de Lavras / Fundação Educacional de Lavras. Rua Padre José Poggel, 506 Centenário, CP.3037, 37200-000 Lavras, MG, Brasil.marconisouza@unilavras.edu.br

${ }^{2}$ Faculdade Gama Filho, Rio de Janeiro, RJ

${ }^{3}$ Setor de Zoologia, Departamento de Biologia, Universidade Federal de Lavras (UFLA), Lavras, Minas Gerais, Brazil. Caixa postal 3037. CEP: 37200-000. drops@ufla.br
}

Journal of Cave and Karst Studies, December 2013•177 


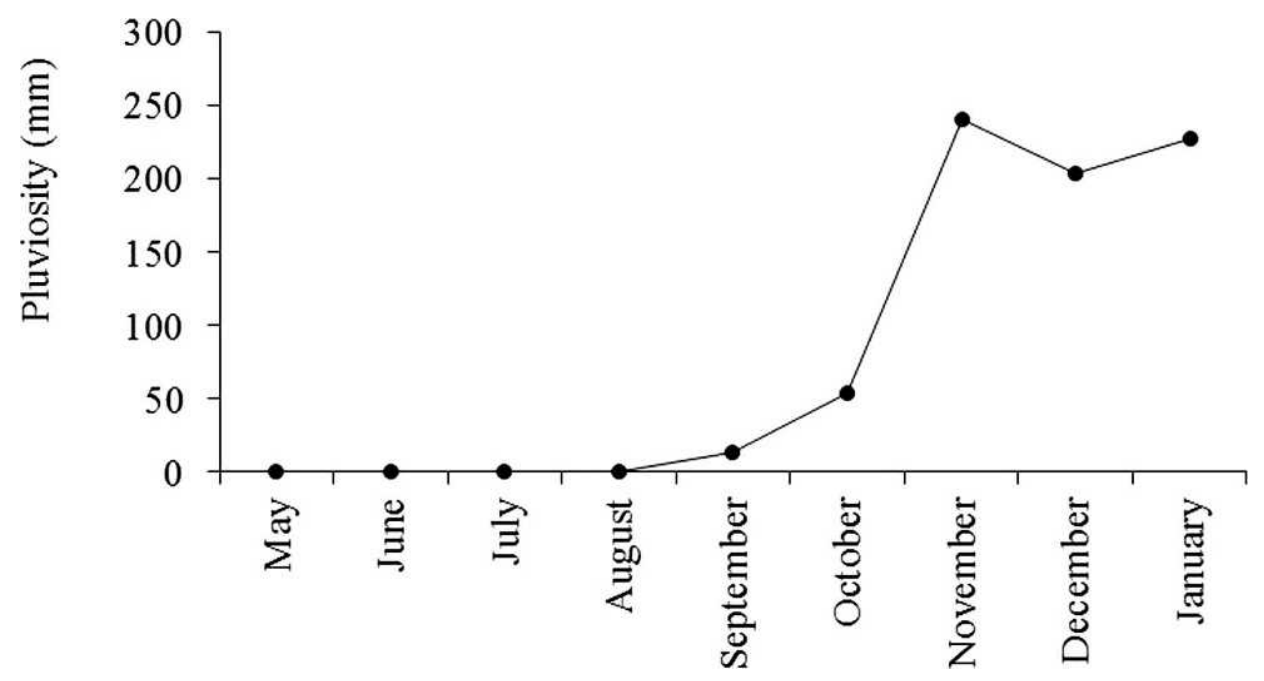

Figure 1. Average rainfall in the vicinity of Casa Cave, Parque Estadual de Ibitipoca, Lima Duarte, Minus Gerais, Brazil.

\section{Methods And Materials}

\section{StUdy AREA}

This research was conducted in the Parque Estadual do Ibitipoca, a conservation area located in the district of Conceição de Ibitipoca in Lima Duarte, in the southeastern part of the state of Minas Gerais in Brazil (23K-615471.15 $\mathrm{E} / 7599906.93 \mathrm{~S}$ ). This park, which is open to tourism, has an area of 1488 ha, varying in altitude from 1300 to $1784 \mathrm{~m}$. The climate is a typical high-altitude tropical climate, with pleasant summers and well-defined wet and dry periods. The study was conducted from May 2004 to January 2005, with the dry season stretching from May to August and the rainy season from August to January (Fig. 1).

The present study was developed in an undeveloped cave in the park, Casas Cave $\left(21^{\circ} 42^{\prime} 39^{\prime \prime} \mathrm{S} 43^{\circ} 53^{\prime} 41^{\prime \prime} \mathrm{W}\right)$, which has 600 meters of linear development and a depth of 39 meters. It has wide passages and ample rooms formed by falling blocks of varying sizes (Fig. 2). The perennial stream in the cave is of allogenic origin. It emerges from a side passage, flows through the main passage, and disappears under breakdown. In addition, seasonal streams arise in different areas inside the cave during the rainy seasons. These are formed by allogenic and autogenic waters and disappear during dry seasons. One of those streams appears near the entrances and flows into the cave in the direction of the main stream. The other two streams rise in one internal chamber upstream; they join the perennial stream in different locations (Fig. 2). A wide variety of sedimentary deposits are found inside the cave, from meter-sized blocks to fine sand of fluvial origin (Silva, 2004). The surrounding vegetation is dense woodlands (Dias et al., 2002).

\section{Litter Production and Transport}

To evaluate litter production and wind transport of coarse particulate organic matter from the exokarst system into the cave, litter traps were installed, both in the cave entrance and in the external environment just outside the cave. Four collectors (basket traps) consisting of $46 \mathrm{~cm}$ diameter metallic hoops covered with nylon net to form $60 \mathrm{~cm}$ cones (Pozo, 2005) were installed in the external zone just outside the two cave entrances, and another four were located 5, 10, or 15 meters just inside the cave entrances (Fig. 2).

In the stream inside the cave, two discrete contentions nets were installed (Fig. 2). The contention nets and the collectors were inspected monthly, and all litter collected was removed. In the laboratory, this litter was separated according to category (leaves, fruit, stems, and animal parts), dried in an oven at $70{ }^{\circ} \mathrm{C}$ for 72 hours, and then weighed. The air temperature and humidity were measured monthly with a manual thermo-hygrometer. Measures of $\mathrm{pH}$ and water temperature were made with a manual thermo- $\mathrm{pH}$ meter. Current speed and discharge volume at two points in the cave stream were determined monthly.

\section{Detritus Processing}

The rate of processing and fragmenting of the organic plant material was determined using plant disks $\left(64 \mathrm{~mm}^{2}\right.$ each) cut from leaves of Philodendrum sp. (Araceae) and inserted into $100 \mathrm{~cm}^{2}$ bags made from $9 \mathrm{~mm}$ nylon net. This plant is typical of quartzite outcrops and is likely to be a source of resources for cave fauna; it can be transported into the interior of the caves by animals, wind, or water. The leaves were collected from the plant prior to abscission to eliminate the possibility that the experimental material had started decomposing on the ground. Each bag was filled with forty disks previously weighed. These bags were then distributed at random points outside the cave, as well as at three points on the ground inside the cave and two in the stream inside the cave (the litterbags of Fig. 2). At the locations where the bags were placed in the water, the speed of the current $\left(\mathrm{m} \mathrm{s}^{-1}\right)$, the temperature $\left({ }^{\circ} \mathrm{C}\right)$, the $\mathrm{pH}$, 


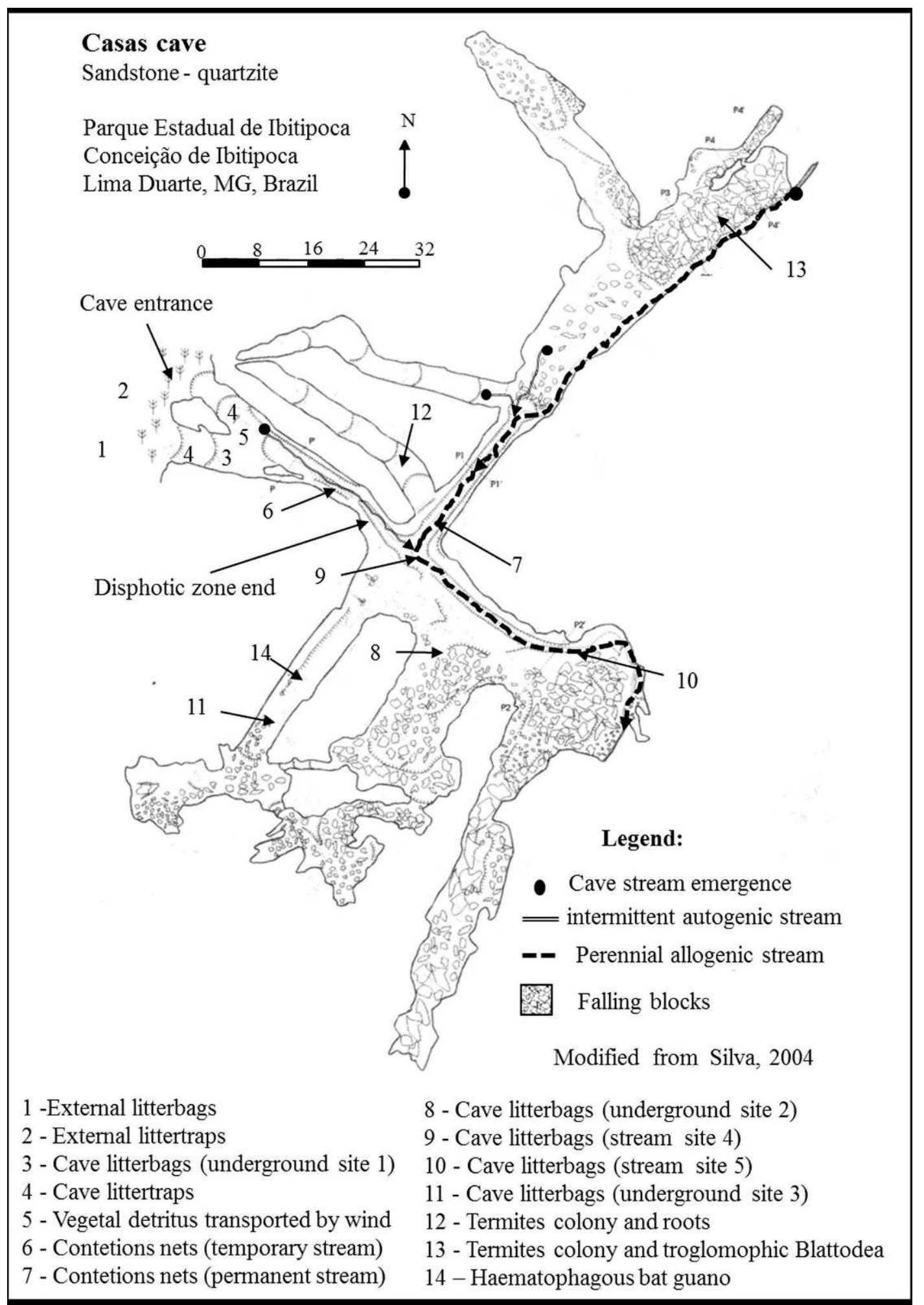

Figure 2. Sample sites of the experimental study of the resource dynamics in Casas Cave, Parque Estadual do Ibitipoca, Brazil.

and the discharge $\left(\mathrm{m}^{3} \mathrm{~s}^{-1}\right)$ were measured. At the points on land inside and outside of the cave, the air temperature $\left({ }^{\circ} \mathrm{C}\right)$ and humidity (\%) were measured. Every two months, three of the bags were removed for depletion analysis that was performed by drying the remains of the disks and then weighing them. The difference in weight was used to determine the processing rate (Gallas et al., 1996, Barlocher, 2005). 


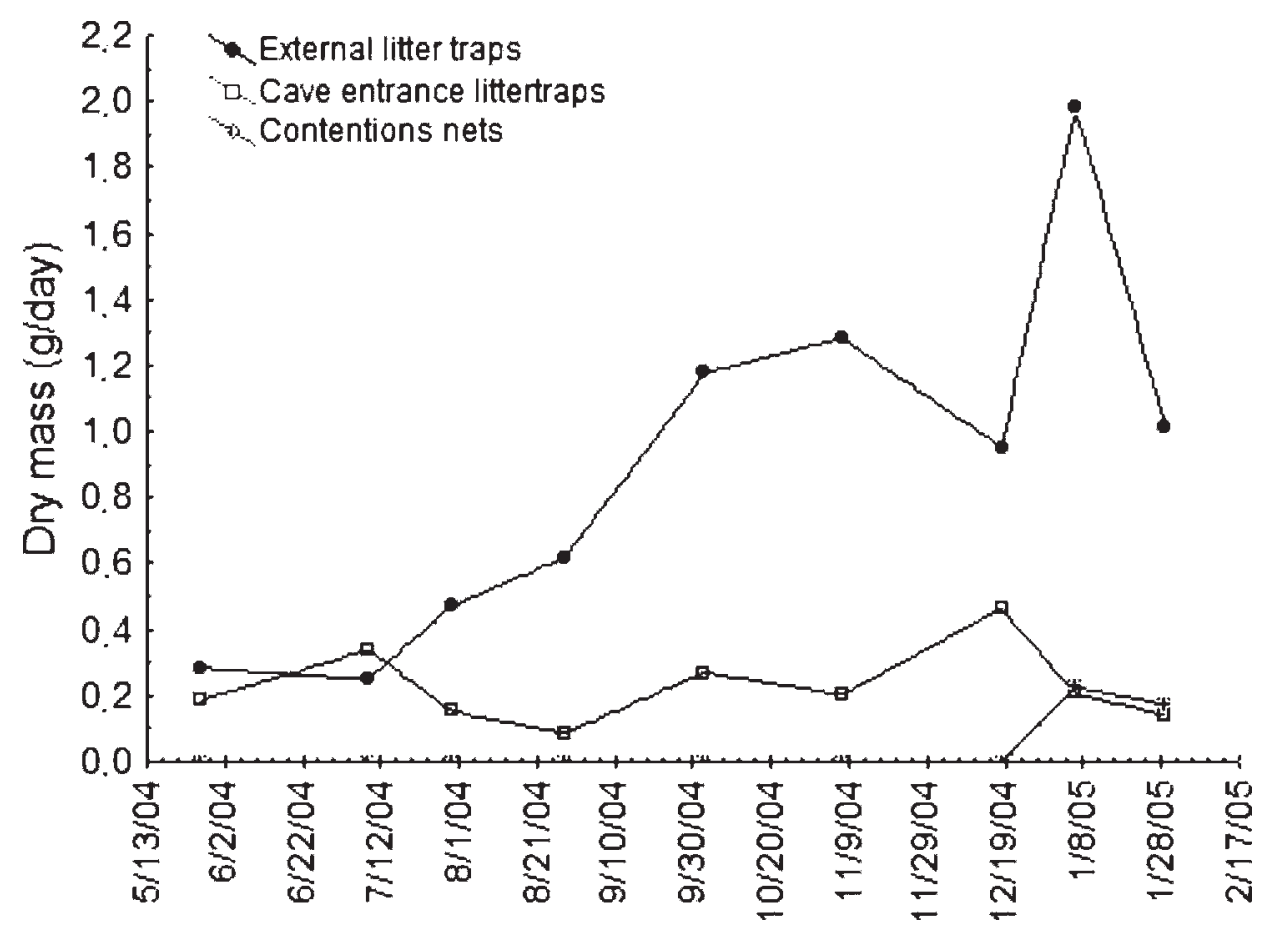

Figure 3. Rate of introduction of organic debris on the surface, in the entrance zone of Casas Cave, Parque Estadual do Ibitipoca, Brazil, and in the cave stream.

\section{Biological InVENTORY/SuRVEY}

The terrestrial invertebrates in the Casas Cave were collected manually towards the end of the experiment in a visual inspection of the microhabitats under rocks, in organic deposits, and along the walls, floor, and ceiling of the cave, as well as in standing pools and running water. To evaluate the distribution and abundance of these invertebrates, the individuals found in the cave were plotted on a cave map (level BCRA-4C) using the methods proposed by Ferreira (2004). All of the organisms collected were identified to the lowest taxonomic level accessible and separated into morphospecies (Souza-Silva et al., 2011a). All of the visible coarse organic matter present was plotted and described in relation to state of deterioration, means of importation into the cave, and associated invertebrates (Fig. 2).

\section{Statistical Analysis}

Linear regressions were used to evaluate the relation between richness and abundance of invertebrates and the distance from the cave entrance (Zar, 1996). The detritus-processing constant $\left(\mathrm{k}^{- \text {day }}\right)$ was determined by fitting the exponential equation $M_{\mathrm{t}}=$ $M_{0} \mathrm{e}^{-k t}$ (Oslon, 1963; Weider and Lang, 1982; Allan, 1995), where $M_{t}$ is the weight at time $t, M_{0}$ the initial weight, and $t$ the exposure time of the sample. The invertebrate trophic relationships were observed during field study.

\section{RESULTS}

In the external environment near the Casas Cave, the average temperature was $18{ }^{\circ} \mathrm{C}( \pm 3 \mathrm{SD})$ and the average humidity was $88 \%$ ( $\pm 6 \mathrm{SD})$. At the entrance of the cave, the average temperature was $18{ }^{\circ} \mathrm{C}( \pm 3 \mathrm{SD})$, and the average humidity $85 \%$ ( $\pm 6 \mathrm{SD})$; inside the cave the average temperature was $21^{\circ} \mathrm{C}( \pm 2 \mathrm{SD})$ and the average humidity, $87 \%( \pm 6 \mathrm{SD})$.

At both of the aquatic points inside the cave, the water temperature varied between 14 and $17{ }^{\circ} \mathrm{C}$, and the water was slightly acidic, with a $\mathrm{pH}$ varying from 3 to 5 . At stream site 4 , the current varied from $0.08 \mathrm{~m} \mathrm{~s}^{-1}$ to $0.164 \mathrm{~m} \mathrm{~s}^{-1}$, with a discharge of between 0.0052 and $0.008 \mathrm{~m}^{3} \mathrm{~s}^{-1}$. At the other point in the water (site 5), the current was somewhat faster, varying between $1.44 \mathrm{~m} \mathrm{~s}^{-1}$ and $0.325 \mathrm{~m} \mathrm{~s}^{-1}$, with a discharge varying from 0.0080 to $0.238 \mathrm{~m}^{3} \mathrm{~s}^{-1}$.

\section{Litter Production and Transport}

More litter mass was collected in the external collectors $\left(0.89 \mathrm{~g} \mathrm{~d}^{-1}\right)$ than in those in the entrance $\left(0.20 \mathrm{~g} \mathrm{~d}^{-1}\right)$ and aphotic cave zone $\left(0.00 \mathrm{~g} \mathrm{~d}^{-1}\right)$ (Fig. 3). The litter collected in May weighed approximately $0.283 \mathrm{~g} \mathrm{~d}^{-1}$ of dry matter and in January $2 \mathrm{~g} \mathrm{~d}^{-1}$ of dry matter. Of the four cave collectors located near the entrance, only that $5 \mathrm{~m}$ from the entrance captured any litter $\left(0.22 \mathrm{~g} \mathrm{~d}^{-1}\right)$. Most of the debris being transported to the interior of the cave by streams and caught in the contention nets consisted of parts of plants, especially leaves and stems, and such debris was encountered only during January, in the rainy season (Figs. 3 and 4).

The outside collectors retained 228 grams of dry organic matter during the course of the experiment, with a predominance of leaves (144 grams); 1.97 grams of animal 


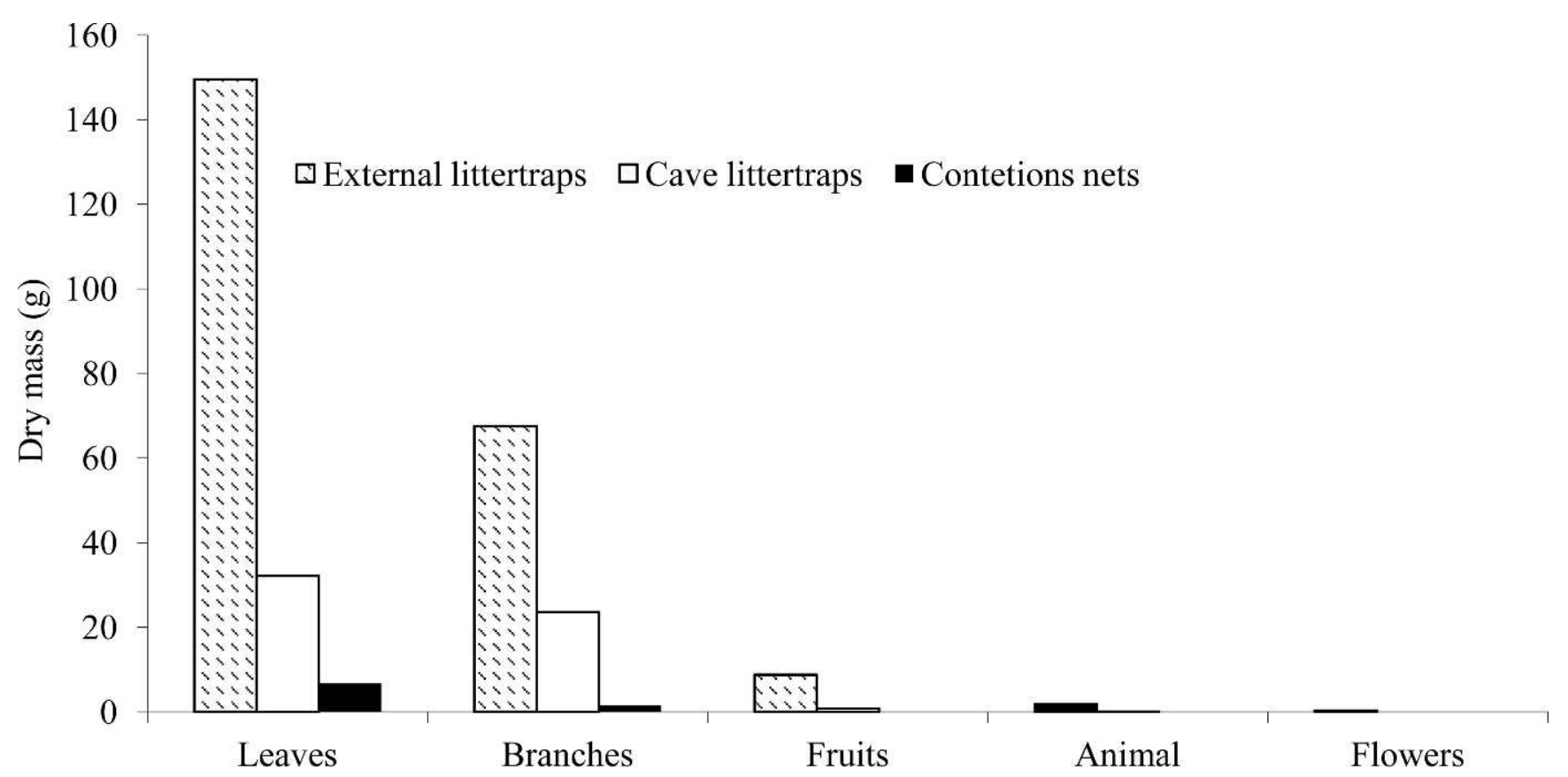

Figure 4. Types of plant detritus collected during the period of observation outside the entrance, in the entrance area of the cave, and in the stream nets.

carcasses were also retained (insects and arachnids). The cave-entrance collectors also captured a greater percentage of leaves (33 grams) than other types, although stems (23.58 grams) and dry fruits (1.11 grams) were also found. In the contention nets, only plant parts were retained: leaves and stems, with 6.75 and 1.54 g, respectively (Fig. 4).

The contention nets installed in the secondary autogenic drainage near the cave entrance collected CPOM being carried by the torrent only in January (Fig. 3). The other two contention nets in the aphotic cave stream contained only sandy material.

\section{Detritus Processing in Cave}

At both points in the water where mesh bags of leaf samples were distributed, there was a loss of $65 \%$ of the mass during the first 25 days (Fig. 5). At stream site 4, the remaining weight decreased to less than $20 \%$ in 186 days of exposure, and after the entire 269 days, only $12 \%$ remained (Fig. 7). At stream site 5, after 119 days of exposure, only $9 \%$ of the plant material remained. After this date, consumption diminished, and only $20 \%$ of the $9 \%$ remaining after 119 days had been consumed by the end of the experiment (Figs. 5 and 7). The processing rate of the plant debris $\left(\mathrm{k}^{- \text {day }}\right)$ in the aquatic environment was moderate to fast. The invertebrates observed in the bags in the stream were Diptera (Chironomidae) and Coleoptera (Elmidae).

During the first 25 days of exposure of the plant debris, there was a rapid drop in the weight at all four sites (50 to $60 \%$ ). In the underground station 1 only $20 \%$ of the mass remained after 155 days. At stations 2 and 3 an average of
$10 \%$ of the mass remained after 250 days. After the 269 days of the experiment, at least some of the plant material remained in all of the mesh bags left in terrestrial environments (Figs. 6 and 7).

The processing rate of the plant debris $\left(\mathrm{k}^{- \text {day }}\right)$ was quite slow in the epigean environment and cave entrance, whereas in the aphotic cave terrestrial zone it was somewhat moderate. Only Pseudonannolene sp. (Diplopoda: Pseudonannolenidae) were found in the hypogean terrestrial bags. Differences in initial and final plant disk masses in terrestrial and aquatic habitats of the Casas Cave are shown in Figure 7.

\section{Invertebrates' Structure and Distribution WITHIN CAVE}

In Casas Cave, sixty-eight species of invertebrates were found. The richest orders were Araneae (18 spp.), Diptera (8 ssp.), Coleoptera (7 spp.), Acari (7 ssp.), and Hymenoptera (6 spp.) (Table 1). Species evidencing troglomorphic traits were from the Pselaphidae ( $1 \mathrm{sp}$.), Blattodea (1 sp.), and Projapygidae (1 sp.). There was a significant and negative relationship between richness $\left(\log _{10}\right)$ and the distance from the cave entrance $\left(\beta=-0.61 ; p<0.002 ; R^{2}\right.$ $=0.37)$, as well as between abundance $\left(\log _{10}\right)$ and the distance from the cave entrance $\left(\beta=-0.52 ; R^{2}=0.26 ; p<\right.$ 0.001) (Fig. 8).

\section{Invertebrate Community and Trophic System}

In the epigean and hypogean environments of Casas Cave, it was possible to delimit three distinct zones with distinct trophic networks: the exokarst (eutrophic), the 


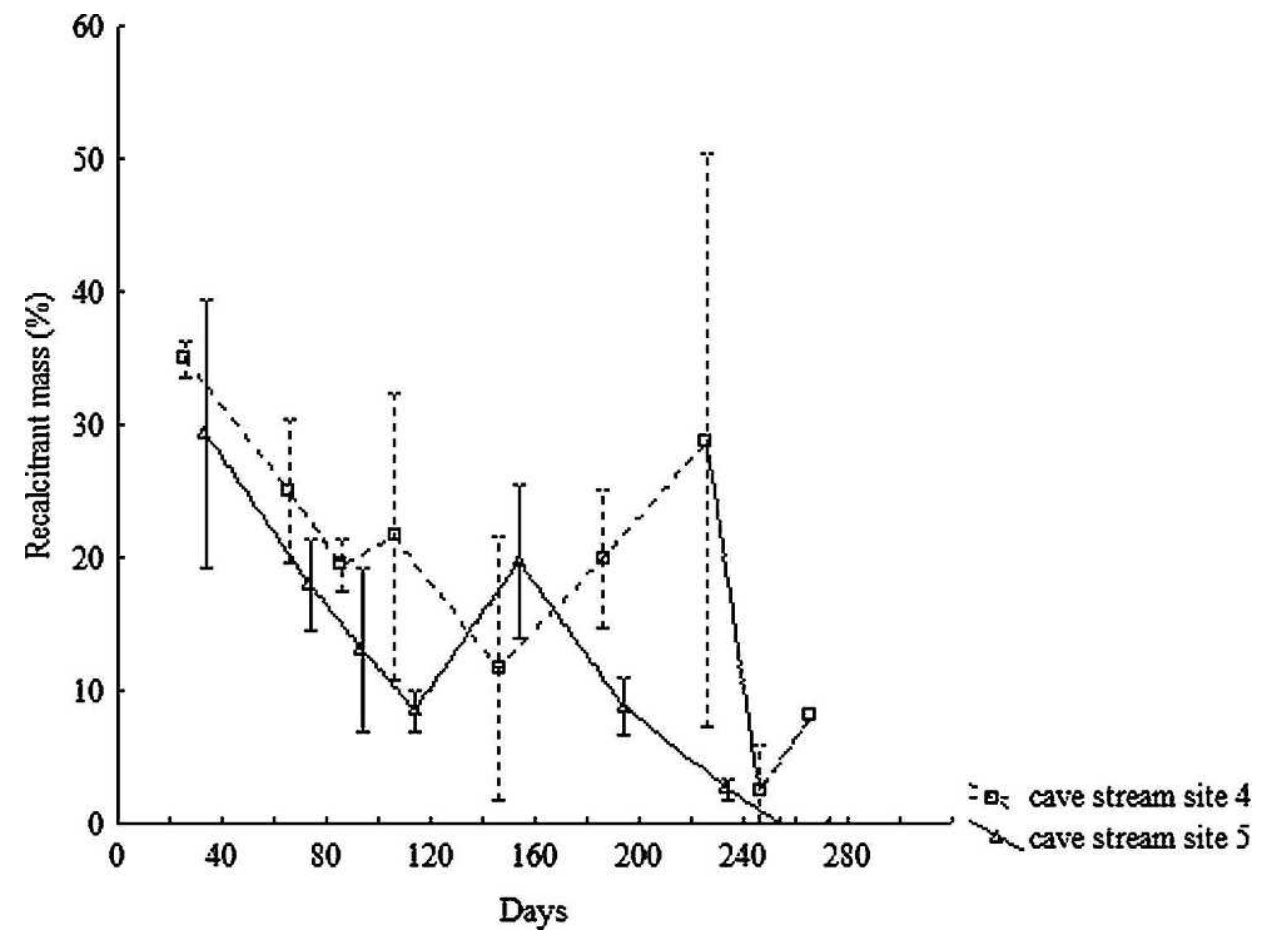

Figure 5. Decay of plant-detritus samples in the stream of Casas Cave, Parque Estadual do Ibitipoca, Brazil (mean and $\pm \mathrm{SD})$.

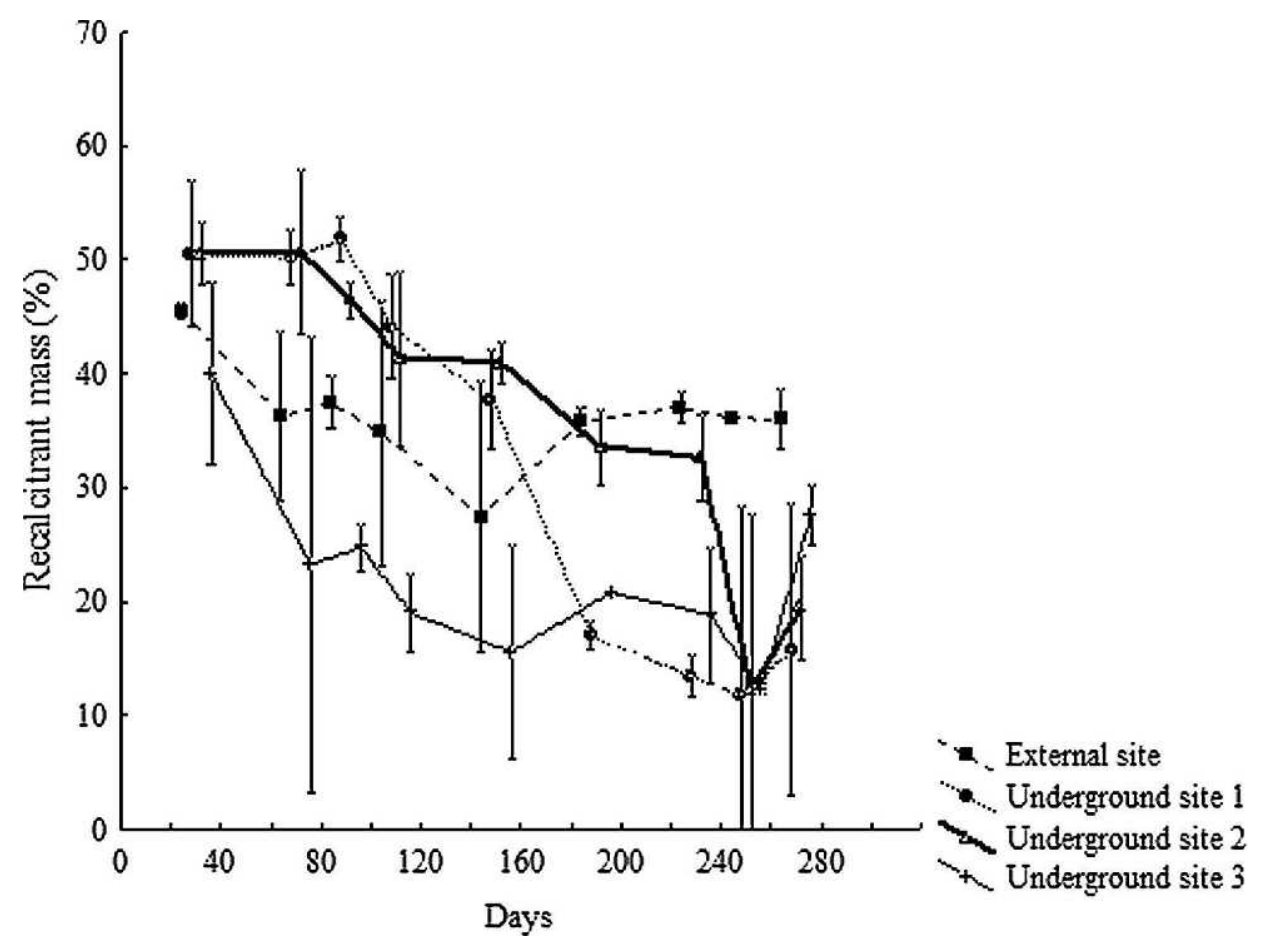

Figure 6. Decay of plant-detritus samples in terrestrial sites of Casas Cave and its exokarst, Parque Estadual do Ibitipoca, Brazil (mean and $\pm \mathrm{SD}$ ). 


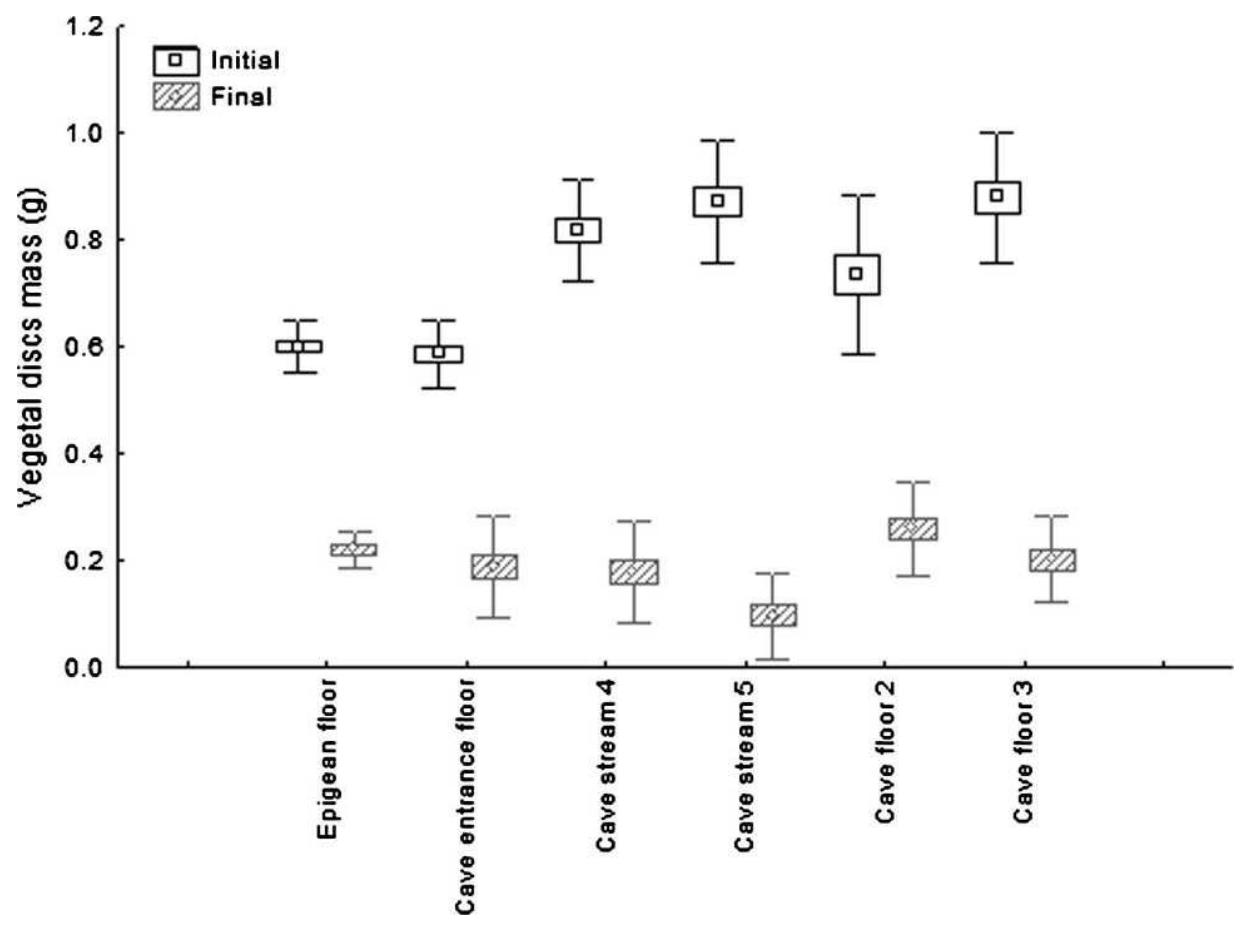

Figure 7. Initial and final plant detritus decay in different places (terrestrial and aquatic) in the quartzite Casas Cave and its exokarst, Parque Estadual do Ibitipoca, Brazil.

cave entrance (mesotrophic), and deepest portion of the cave (oligotrophic).

In the exokarst environment surrounding the entrance of Casas Cave, the dense rain forest produced more leaf litter during the rainy months of the year than during the dry months (Fig. 3). The slow processing rate of this plant debris and the limited transport of the coarse particulate organic matter (CPOM) resulted in the accumulation of a large amount, and in this environment, food resources were plentiful for invertebrates.

In the disphotic region of the cave, near to the entrance, the main food resources were ferns, mosses and scarce litter (leaves and branches from the surrounding trees). More CPOM was blown into Casas Cave during the rainy season than during the dry season, although this accumulated near the entrance of the cave. The downward-sloping floor is composed of highly permeable sand strewn with boulders, so it functions as a filter for the debris, with water passing easily, while the particulate material is retained. In this environment, processing is slow, although the low foodresource transport rate does promote accumulation. Given the slow processing rate, the system was classified as mesotrophic. The scavenger invertebrates found there were Turbellaria, Acari, Phalangopsidae, Tenebrionidae,
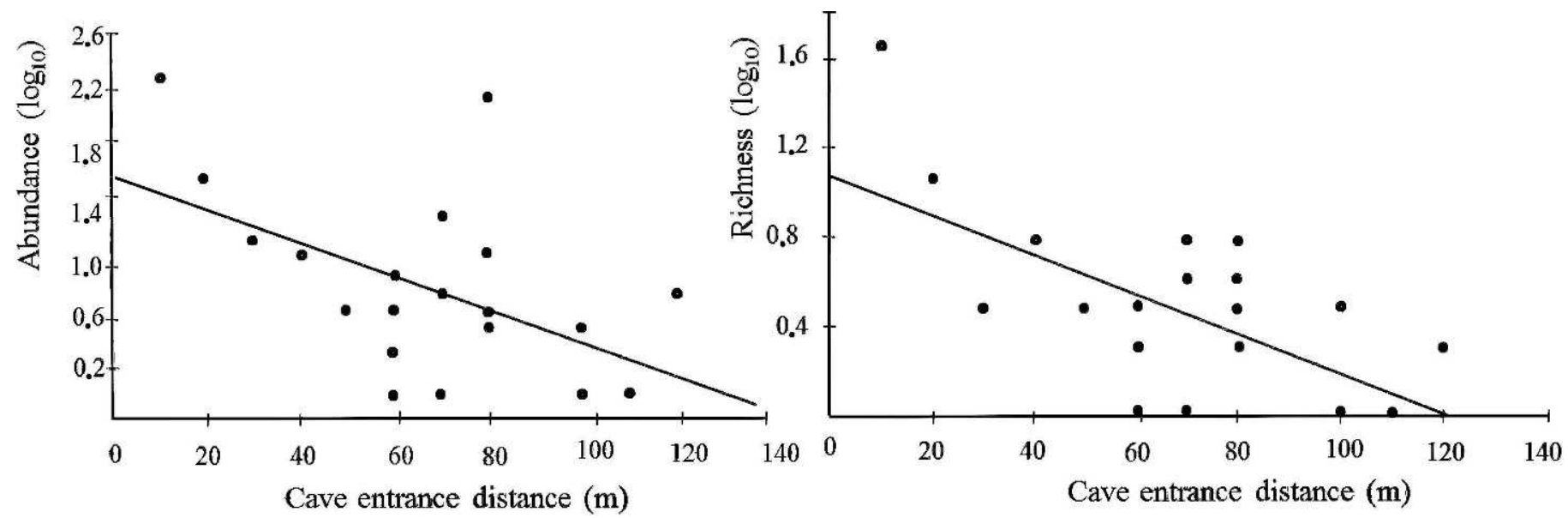

Figure 8. Relationship between invertebrate abundance and richness $\left(\log _{10}\right)$ with entrance distance in Casas Cave. 
Table 1. Invertebrate communities structure in Casas Cave, Parque Estadual do Ibitipoca, Brazil.

\begin{tabular}{|c|c|c|c|}
\hline \multirow[b]{2}{*}{ Taxons } & \multirow[b]{2}{*}{ Taxons } & \multicolumn{2}{|c|}{ Morpho-Species } \\
\hline & & Cave Floor & Cave Stream \\
\hline Platyhelminthes & Dugesiidae & 2 & \\
\hline Oligochaeta & NI & & 1 \\
\hline Acari & $\mathrm{NI}$ & 6 & 1 \\
\hline \multirow[t]{8}{*}{ Araneae } & Ctenidae (Ctenus sp. Enoploctenus sp.) & 2 & \\
\hline & Pholcidae (Mesabolivar sp.) & 1 & \\
\hline & Dipluridae & 3 & \\
\hline & Theraphosidae & 1 & \\
\hline & Orthognatha & 1 & \\
\hline & Theridiidae & 1 & \\
\hline & Theridiosomatidae (Plato sp.) & 1 & \\
\hline & Ochyroceratidae & 1 & \\
\hline Opiliones & Gonyleptidae (Goniosoma sp.) & 1 & \\
\hline Palpigradi & Eukoeneniidae (Eukoenenia sp.) & 1 & \\
\hline Pseudoscorpionida & Chernetidae & 1 & \\
\hline Diplopoda & Pseudonannolenidae (Pseudonannolene sp.) & 1 & \\
\hline \multirow[t]{2}{*}{ Chilopoda } & Lithobiomorpha & 2 & \\
\hline & Geophilomorpha & 1 & \\
\hline Collembola & Entomobryidae & 3 & \\
\hline \multirow[t]{5}{*}{ Coleoptera } & Tenebrionidae & 1 & \\
\hline & Curculionidae & 1 & \\
\hline & Pselaphidae & 2 & \\
\hline & Scarabaeidae & 1 & \\
\hline & Elmidae & & 2 \\
\hline Diplura & Projapygidae & 1 & \\
\hline \multirow[t]{2}{*}{ Blattaria } & NI & 1 & \\
\hline & NI & 1 & \\
\hline \multirow[t]{5}{*}{ Diptera } & Chironomidae & & 2 \\
\hline & Tipulidae & & 1 \\
\hline & Culicidae & 1 & \\
\hline & Phoridae (Conicera sp) & 1 & \\
\hline & Mycetophilidae & 1 & \\
\hline Ensifera & Phalangopsidae (Endecous sp.) & 2 & \\
\hline Ephemeroptera & NI & & 3 \\
\hline \multirow[t]{3}{*}{ Heteroptera } & NI & 1 & \\
\hline & Reduviidae (Zelurus sp.) & 1 & \\
\hline & Ploiaridae & 1 & \\
\hline \multirow[t]{2}{*}{ Hymenoptera } & Formicidade & 5 & \\
\hline & NI & 1 & \\
\hline Homoptera & NI & 1 & \\
\hline Isoptera & Nasutitermitinae & 1 & \\
\hline \multirow[t]{2}{*}{ Plecoptera } & Perlidae & & 1 \\
\hline & Gripopterygidae & & 1 \\
\hline Psocoptera & Psyllipsocidae & 1 & \\
\hline Trichoptera & Leptoceridae & & 1 \\
\hline Richness & & 55 & 13 \\
\hline
\end{tabular}

Scarabaeidae, Curculionidae, Pselaphidae, Formicidae, Leptoceridae and Psocoptera; the predators were limited to Reduviidae, Ploiaridae (Emesiinae), Ctenidae, Pholcidae, Dipluridae, Ctenizidae, Theridiidae, and Ochyroceratidae. Culicidae and Gonyleptidae used the cave entrance for shelter, although they have to leave temporarily in search of food in the surrounding area (Fig. 9).

In the deeper portions of the cave, plant debris was scarce, resulting in an oligotrophic environment. Most of the food resources available were limited to mineralized 
External zone

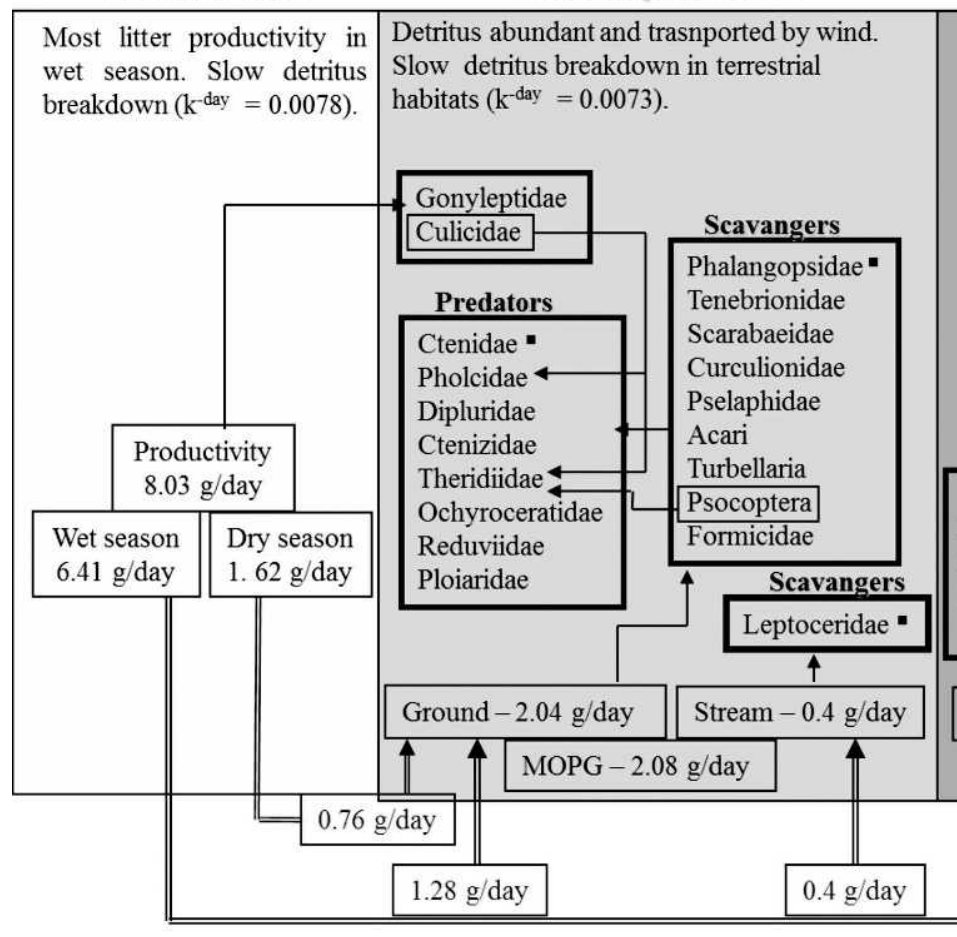

Cave aphotic zone

Without plant debris. In terrestrial habitats bat guano present is scarce and old. The basis of the food web is scarce termites gallery and roots. Moderate detritus breakdown in terrestrial habitats $\left(\mathrm{k}^{\text {day }}=0.0064-0.0185\right)$ and moderate to fast in stream $\left(\mathrm{k}^{\text {day }}=0.0208-0.0277\right)$.

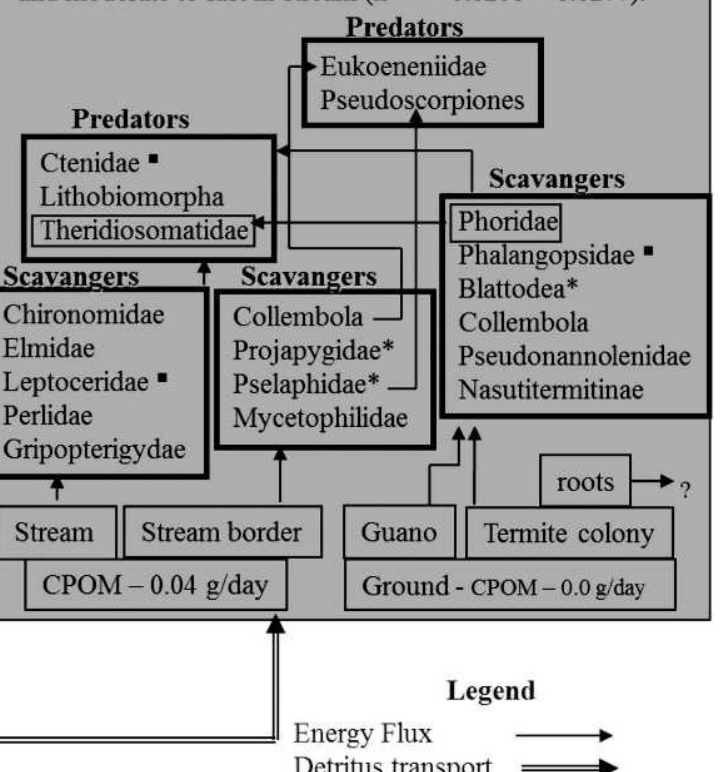

Detritus transport $\longrightarrow$

CPOM - Coarse particulate organic matter

* Troglomorphic taxa

- Occurrence in disphotic and aphotic zone

Figure 9. Trophic dynamics in Casas Cave and its exokarst, Parque Estadual de Ibitipoca, Brazil.

guano, as well as the detritus left by termite colonies established at isolated locations around the cave; few roots from external plants had penetrated the ceiling. In this deeper environment of the cave, the scavengers were Chironomidae, Elmidae, Leptoceridae, Perlidae, Gripopterigydae, Projapygidae, Pselaphidae, Mycetophilidae, Phoridae, Phalangopsidae, Blattodea, Collembola, Pseudonannolenidae and Nasutitermitinae found in guano and the termite nests. The predators were Ctenidae, Theridiosomatidae, Pseudoscorpiones, Palpigradi, and Lithobiomorpha (Fig. 9).

\section{DisCUSSION}

The invertebrate fauna composition in Casas Cave, especially in relation to families, is similar to that registered in other quartzite caves in the state of Minas Gerais (Ferreira, 2004; Souza-Silva et al., 2011b). The invertebrates collected in Casas Cave were located largely near the cave entrance, becoming progressively less rich and abundant as one penetrates farther into the cave. This is due to the scarcity of organic resources in the more internal portions of the cave. This picture of intense oligotrophy in the more internal portions may be what is determining the relatively greater richness of species associated with the entrance areas (Prous et al., 2004; Li, 2006).
The depth of light penetration in a cave entrance depends on the position, general direction, and shape of the conduit, as well as the size of the cave entrance. The light gradually loses its intensity and changes in spectral content with increasing distance from the entrance (Sket, 2004). Phototrophic organisms are present, but gradually disappear towards deeper zones. Flowering plants are the first group to disappear, followed by ferns, mosses, green algae, and finally cyanobacteria (Sket, 2004; Pentecost, 2004). These habitats are considered as ecotones between the surface and dark cave habitats (Sket, 2004; Prous et al., 2004).

The absence of fresh guano deposits in the interior of the cave suggests that bats no longer inhabit the cave, though in the past various colonies were established and regularly deposited guano in the interior rooms. The colonization of caves by bats is important for the constant production of guano and the maintenance of a welldeveloped invertebrate cave community's structure, especially in permanently dry cave environments (Souza-Silva et al., 2011; Ferreira and Martins, 1999). The abandonment of this cave by the bats may have been a consequence of the intense flow of tourists along the trail to the park's administration center, located some $200 \mathrm{~m}$ from the cave entrance. Moreover, the trail remains illuminated at night, and this may also have influenced bats' habits, leading

Journal of Cave and Karst Studies, December 2013•185 
them to seek refuge in other caves of the region. Abandonment by bats has probably contributed to the intense trophic poverty encountered in many of the caves in the park in the middle and long term.

The relationship of litter fall to rainfall can depend on vegetation type, as well as weather conditions. Outside Casas Cave debris accumulates on the ground in greater quantities during the rainy season, although there is higher humidity of the air and greater availability of water in the hydromorphic sandy soil. The rain-forest environment here may lead to less leaf loss from water stress than is typical elsewhere due to greater amounts of sunshine during drier periods.

Since the sandy soil at the entrance of the cave is very permeable, rain water rapidly filters through it. This hinders the formation of floods that could transport coarse particulate organic matter into the cave and also carries any dissolved organic matter to deeper layers of the soil. The CPOM in the cave is mainly blown in by wind as it falls from the trees. The force of this wind, however, is insufficient to transport the CPOM very deeply into the cave. Limestone caves also tend to experience greater transport of debris into the hypogean environment during the rainy season (Souza-Silva et al., 2011; Souza-Silva et al., 2007). However, in contrast to what happens in the quartzite surroundings of Casas Cave, forests in limestone areas have well-defined phenophases and produce somewhat more leaf litter during dry periods (Brina, 1998). The limited production of leaf litter in the exokarst around Casas Cave during the dry period may be related to the dense fog that frequently covers the higher areas of the Parque Estadual do Ibitipoca all year round.

Surface streams in riparian forests may receive large amounts of CPOM, transporting it into caves when passing through the swallets connected to the hypogean environments. Leaves and branches that have fallen to the ground are also moved more easily during periods of rapid water flow resulting from intense rains (Webster et al., 1999). But for Casas Cave, the low rate of CPOM transport is at least partially determined by the epikarstic hydraulic dynamics above the cave. Some streams arise from the water percolating through the ceiling or flow for long stretches through and around fallen rocks; these conditions filter out all CPOM. This means that the resulting trophic webs will have limited food resources and be generally less complex, based mainly on biofilms, with invertebrate communities largely consisting of filtering organisms (Simon et al., 2003). Litter exclusion in stream influences local food webs (Wallace et al., 1997). The exclusion led to accelerated breakdown by reducing nutrient limitation (Tank and Webster, 1998). Limestone cave streams without openings to the surface are fed by water percolated through the soil and bedrock. Such disconnected streams receive only fine particulate organic matter and dissolved organic matter transported through small fractures in the rock (Simon and Benfield, 2001).
The occurrence of additional resources derived from termite dens and the garbage dumps of ants is rare in cave environments, so their utilization by invertebrates is limited. Such resources rarely function as the trophic basis for more complex food webs in caves (Ferreira, 2000). However, in Casas Cave, the presence of such resources, coupled with the limited availability of other options, has changed the situation, and here one finds an abundance of organisms associated with and close to the termite nest.

Leaves in streams, disconnected from the surface, break down at slow rates, generally similar to those found in lakes and low-order streams (Simon and Benfield, 2001). However, the processing of plant debris in the hypogean stream in Casas Cave is similar to that found in hypogean streams connected to the surface (Simon and Benfield, 2001). Leaves in hypogean streams disconnected to the surface lose mass slowly, and at roughly the same rate as wood. Leaf breakdown is relatively fast in hypogean streams connected to the surface (Simon and Benfield, 2001). Initial rates of nutrient loss are fast due to leaching by the abrasive force of the water. Moreover, the moderate processing can be under influence of recalcitrant Philodendrum leaves and little richness of shredding invertebrates.

The difference in the processing rates observed for the two sample sites in the stream inside the cave is probably related to the greater discharge and current speed at site 5, where small neighboring streams flow into the main stream. The scarcity of shredding invertebrates also suggests that the main agent for processing organic plant material in the aquatic environment of this cave is the physical and chemical action of the water.

In the terrestrial environment, high temperature and humidity are fundamental for rapid decomposition, since these regulate the metabolism of the decomposing organisms; these conditions can also cause differential liberation of phenolic compounds and the leaching of leaves during decomposition (Nicolai, 1988). According to Souza-Silva et al. (2011), unfavorable environmental conditions such as low humidity and low soil temperature may inhibit colonization by animals and decrease the rate of plantdebris processing in terrestrial environments in caves. The relatively low rates of plant debris processing found in the terrestrial environments inside Casas Cave may be due, at least partially, to the lack of favorable soil humidity, as this may have caused the low richness and abundance of fragmenting invertebrates. The somewhat larger processing rate at site 3 may reflect the presence of a more humid soil, which does permit the activity of the fragmenting invertebrates present (Diplopoda), especially since percolating water dripped directly onto the litterbags (Humphreys, 1991).

There are no studies at the moment concerning organic matter dynamics and its relation to invertebrate communities in quartzite caves. However, at least for some Brazilian limestone caves, there is some available information concerning trophic relations in guano invertebrate 
communities (Ferreira and Martins, 1998; Ferreira and Martins, 1999; Ferreira et al., 2000, 2007). Since the guano is an ephemeral resource, the associated communities can frequently exhibit a dynamic succession related to the changing condition of the guano. The presence of resident bat colonies, however, can provide constant renewal of the organic matter (Ferreira et al., 2000).

The food web (as well as the invertebrate communities that form it) found at Casas Cave is similar to that described for other Brazilian caves, based on anthill garbage, roots, dead animals, guano, and detritus (Ferreira and Martins, 1999; Ferreira, 2000). The main scavenger species found in Casas Cave, as well as their predators, belong to families commonly found in other Brazilian cave organic substrates.

Considerable differences can be observed when comparing the communities associated with the euphotic/ disphotic and aphotic zones of the cave (Fig. 9). Such differences are more evident considering the taxa substitution and low similarity between these communities. These two zones represent distinct compartments located in a same cave. Most of the trophic resources brought into the disphotic/euphotic zone by water or wind remain there and provide favorable conditions for the establishment of many invertebrate species. These facts make us question some important issues. How interactive are the para-epigean and hypogean communities? What are the actual contributions of ecological, environmental, and evolutionary conditions in determining the distribution of species in a cave?

Since food resources are limited in deep zones of the cave, most species might "prefer" areas near the entrance (Machado et al., 2001; Prous et al., 2004). However environmental conditions such as temperature and humidity are much more variable than in the deep zones. On the other hand, the environmental stability found in the deep zones is almost always combined with a scarcity of food resources. Because of these differences, the communities become clearly distinct, possibly due to competitive exclusion. According to the literature, species that are more specialized are well adapted to the scarcity of food in the deep zones. These organisms also have lower waterretention capacity due to their thin cuticle and greater surface in relation to their body mass (Culver, 1982).

Culver and Poulson (1970) previously demonstrated that the fauna in the temperate entrance zone of Cathedral Cave are more similar to the fauna inside than outside the cave. Contrary to that, Prous and colleagues (2004) have demonstrated a higher invertebrate similarity between the epigean and ecotone region in two tropical caves, suggesting that the external environment in tropical systems is more important as a source of potential species to colonize the ecotone.

The ecotone, at least for the studied cave, may function as a filter between the two adjacent environments, allowing only pre-adapted organisms to cross it and thus to colonize the cave. The low richness observed in deep zones of the cave could reflect not only food scarcity, but also a strong "filter effect" imposed by the rich community established near the cave entrances.

\section{Conclusions}

This study has investigated the food-resource availability in a quartzite caves at high elevation in the Atlantic Rain Forest region of Brazil and its influence on the invertebrate fauna distribution and abundance. In such environments, the transfer of allochthonous resources to interior regions of the cave is critical to foster invertebrate diversity. The amount of debris transferred into any cave depends on litter fall during the rainy season and consequent transport of coarse particulate organic matter into the cave.

The presence of tourism in and around the caves and pseudokarst of the state park of Ibitipoca investigated here seems to have disturbed the historic bat population and fostered their abandonment of the cave studied, thus contributing to a decrease in the availability of food resources for the invertebrate fauna.

The trophic relationships identified here sustain only a fragile community of invertebrates, and these results suggest that similar issues should be considered for other caves, since the maintenance of invertebrate and even vertebrate communities often depends on the integrity of the encompassing exokarst.

\section{ACKNOWLEDGEMENTS}

The authors would like to acknowledge the assistance of the employees of the Parque Estadual de Ibitipoca (IEF MG) for their support. The Critical Ecosystem Partnership Fund (CEPF), Conselho Nacional de Pesquisa (CNPq), Fundação de Amparo a pesquisa do Estado de Minas Gerais (Fapemig), Instituto Chico Mendes (ICMbio), Sociedade Brasileira de Espeleologia (SBE), Centro Nacional de pesquisa e conservação de cavernas (CECAV) provided funding for the project.

\section{REFERENCES}

Allan, J.D., 1995, Stream Ecology - Structure and Function of Running Waters: Oxford, Alden Press, 377 p.

Barlocher, F., 2005, Leaf mass loss estimated by litter bag technique. In Methods to study litter decomposition: a practical guide. Manuel A.S. Graça, Felix Barlocher, and Mark O. Gessner, eds., Published by Springer, P.O. Box 17, 3300 AA Dordrecht, the Netherlands, p. 3742.

Boling, Jr., R.H., Goodman, E.D., Van Sickle, J.A., Zimmer, J.O., Cummings, K.W., Petersen, R.C., and Reice, S.R., 1975, Toward a model of detritus processing in a woodland stream: Ecology, v. 56, p. 141-151. doi:10.2307/1935306.

Brina, A.E., 1998, Aspectos da dinâmica da vegetação associada a afloramentos calcários na APA Carste de Lagoa Santa, MG [Masters Thesis]: Belo Horizonte, Universidade Federal de Minas Gerais, $105 \mathrm{p}$.

Chivian, D., Brodie, E.L., Alm, E.J., Culley, D.E., Dehal, P.S., DeSantis, T.Z., Gihring, T.M., Lapidus, A., Lin, Li-Hung, Lowry, S.R., Moser,

Journal of Cave and Karst Studies, December 2013•187 
D.P., Richardson, P.M., Southam, G., Wanger, G., Pratt, L.M., Andersen, G.L., Hazen, T.C., Brockman, F.J., Arkin, A.P., and Onstott, T.C., 2008, Environmental genomics reveals a single-species ecosystem deep within Earth: Science, v. 322, p. 275-278. doi:10.1126/ science. 1155495.

Culver, D.C., 1982, Cave Life: Cambridge, Massachusetts, Harvard University Press, $189 \mathrm{p}$.

Dias, H.C.T., Filho, E.I.F., Schaefer, C.E.G.R., Fontes, L.E.F., and Ventorim, L.B., 2002, Geoambientes do Parque Estadual do Ibitipoca, Município de Lima Duarte, MG: Revista da Árvore, v. 26, p. 777-786. doi:10.1590/S0100-67622002000600014.

Ferreira, R.L., 2000, "Lixeiras de formigueiros": recursos adicionais em sistemas cavernícolas?: O Carste, v. 12, p. 154-158.

Ferreira, R.L., 2004, A medida da complexidade ecológica e suas aplicações na conservação e manejo de ecossistemas subterrâneos [Ph.D. thesis]: Belo Horizonte, Universidade Federal de Minas Gerais, $161 \mathrm{p}$.

Ferreira, R.L., and Martins, R.P., 1998, Diversity and distribution of spiders associated with bat guano piles in Morrinho Cave (Bahia State, Brazil): Diversity and Distributions, v. 4, p. 235-241.

Ferreira, R.L., and Martins, R.P., 1999, Trophic structure and natural history of bat guano invertebrate communities, with special reference to Brazilian caves: Tropical Zoology, v. 12, p. 231-252.

Ferreira, R.L., Prous, X., and Martins, R.P., 2007, Structure of bat guano communities in a Brazilian dry cave: Tropical Zoology, v. 20, p. $55-74$.

Ferreira, R.L., Yanega, D., and Martins, R.P., 2000, Ecology of bat guano arthropod communities in a Brazilian dry cave: Ecotropica, v. 6 , p. $105-116$.

Ferreria, R.L., 2005, A vida subterrânea nos campos ferruginosos. O Carste, v. 3, 17, p. 106-115.

Galas, J., Bednarz, T., Dumnicka, E., Starzecka, A., and Wojtan, K., 1996, Litter decomposition in a mountain cave water: Archiv für Hydrobiologie, v. 138, p. 199-211.

Graening, G.O., 2000, Ecosystem dynamics of an Ozark cave [Ph.D. thesis]: Fayetteville, University of Arkansas, 99 p.

Hills, N., Hose, G.C., Cantlay, A.J., and Brad, R.M., 2008, Cave invertebrate assemblages differ between native and exotic leaf litter: Austral Ecology, v. 33, p. 271-277. doi:10.1111/j.1442-9993.2007. 01814.x.

Hooper, D.U., Bignell, D.E., Brown, V.K., Brussard, L., Dangerfield, J.M., Wall, D.H., Wardle, D.A., Coleman, D.C., Giller, K.E., Lavelle, P., Van Der Putten, W.H., Ruiter, P.C., Rusek, J., Silver, W.L., Tiedje, J.M., and Wolters, V., 2000, Interactions between aboveground and belowground biodiversity in terrestrial ecosystems: patterns, mechanisms, and feedbacks: BioScience, v. 50, p. 1049 1061. doi:10.1641/0006-3568(2000)050[1049:IBAABB]2.0.CO;2.

Hose, L.D., Palmer, A.N., Palmer, M.V., Northup, D.E., Boston, P.J., and DuChene, H.R., 2000, Microbiology and geochemistry in a hydrogen-sulphide-rich karst environment: Chemical Geology, v. 169, p. 399-423. doi:10.1016/S0009-2541(00)00217-5.

Humphreys, W.F., 1991, Experimental re-establishment of pulse-driven populations in a terrestrial troglobite community: Journal of Animal Ecology, v. 60, p. 609-623.

Jasinska, E.J., Knott, B., and McComb, A.J., 1996, Root mats in groundwater: a fauna-rich cave habitat: Journal of the North American Benthological Society, v. 15, p. 508-519.

Jordan, C.F., 1985, Nutrient Cycling in Tropical Forest Ecosystems: Principles and Their Application in Management and Conservation: Hoboken, Wiley, $190 \mathrm{p}$.

Li, Doa-Hong, 2006, Correlation between the animal community structure and environmental factors in Dongbei Cave and Shuijiang Cave of Guizhou Province: Zoological Research, v. 27, no. 5, p. 481-488.

Machado, S.F., Ferreira, R.L., and Martins, R.P., 2003, Aspects of the population ecology of Goniosoma sp. (Arachnida, Opiliones, Gonyleptidae) in limestone caves in Southeastern Brazil: Tropical Zoology, v. 16, p. $13-31$.

Nicolai, V., 1988, Phenolic and mineral content of leaves influences decomposition in European forest ecosystems: Oecologia, v. 75, p. 575-579. doi:10.1007/BF00776422.
Oslon, J.S., 1963, Energy storage and the balance of producers and decomposers in ecological systems: Ecology, v. 44, p. 322-331. doi: $10.2307 / 1932179$.

Pentecost, A., 2004, Entrance habitats, in Gunn, J., ed., Encyclopedia of Caves and Karst Science: New York, Taylor and Francis, p. 318-319.

Pozo, J., 2005, Coarse particulate organic matter budgets. In Methods to study litter decomposition: a practical guide. Manuel. A.S. Graça, Felix Barlocher, and Mark O. Gessner, eds., Published by Springer, P.O. Box 17, 3300 AA Dordrecht, The Netherlands, p. 43-50.

Prous, X., Ferreira, R.L., and Martins, R.P., 2004, Ecotone delimitation: epigean-hypogean transition in cave ecosystems: Austral Ecology, v. 29 , p. 374-382. doi:10.1111/j.1442-9993.2004.01373.x.

Rodriguez, S.R., 2000, Transferencia de recursos alimentarios entre diferentes ambientes del ecosistema marino: Revista Chilena de Historia Natural, v. 73, p. 199-207. doi:10.4067/S0716-078X2000000100017.

Sarbu, S.M., Kane, T.C., and Kinkle, B.K., 1996, A chemoautotrophically based cave ecosystem: Science, v. 272, p. 1953-1955. doi:10.1126/ science. 272.5270 .1953 .

Schneider, K., Christman, M.C., and Fagan, W.F., 2011, The influence of resource subsidies on cave invertebrates: results from an ecosystemlevel manipulation experiment: Ecology, v. 92, p. 765-776. doi:10. 1890/10-0157.1.

Silva, S.M., 2004, Carstificação em rochas siliciclásticas: estudo de caso na Serra do Ibitipoca, Minas Gerais [Masters thesis]: Belo Horizonte, Universidade Federal de Minas Gerais, 142 p.

Simon, K.S., and Benfield, E.F., 2001, Leaf and wood breakdown in cave streams: Journal of the North American Benthological Society, v. 20, p. $550-563$.

Simon, K.S., Benfield, E.F., and Macko, S.A., 2003, Food web structure and the role of epilithic biofilms in cave streams: Ecology, v. 84, p. 2395-2406. doi:10.1890/02-334.

Simon, K.S., Pipan, T., and Culver, D.C., 2007, A conceptual model of the flow and distribution of organic carbon in caves: Journal of Cave and Karst Studies, v. 69, p. 279-284.

Sket, B., 2004, Subterranean habitats, in Gunn, J., ed., Encyclopedia of Caves and Karst Science: New York, Taylor and Francis, p. 709-713.

Souza-Silva, M., Martins, R.P., and Ferreira, R.L., 2011, Trophic dynamics in a neotropical limestone cave, Subterranean Biology, v. 9, p. 127-138. doi:10.3897/subtbiol.9.2515.

Souza-Silva, M., Martins, R.P., and Ferreira, R.L., 2011a, Cave lithology determining the structure of the invertebrate communities in the Brazilian Atlantic Rain Forest: Biodiversity and Conservation, v. 20, p. 1713-1729. doi:10.1007/s10531-011-0057-5.

Souza-Silva, M., Nicolau, J.C., and Ferreira, R.L., 2011b, Comunidades de invertebrados terrestres de três cavernas quatzíticas Vale do Mandembe, Luminárias, MG: Espeleo-Tema, v. 22, p. 151-167.

Souza-Silva, M., Bernardi, L.F., de, O., Martins, R.P., and Ferreira, R.L., 2012, Transport and consumption of organic detritus in a neotropical limestone cave: Acta Carsologica, v. 41, p. 139-150.

Souza-Silva, M., Ferreira, R.L., Bernardi, L.F. de, O., and Martins, R.P., 2007, Importação e processamento de detritos orgânicos em uma caverna calcária: Espeleo-Tema, v. 19, p. 31-41.

Tank, J.L., and Webster, J.R., 1998, Interaction of substrate and nutrient availability on wood biofilm processes in streams: Ecology, v. 79, p. 2168-2179. doi:10.1890/0012-9658(1998)079[2168:IOSANA]2.0.CO;2.

Venarsky, M.P., Benstead, J.P., and Huryn, A.D., 2012, Effects of organic matter and season on leaf litter colonization and breakdown in cave streams: Freshwater Biology, v. 57, p. 773-786. doi:10.1111/j.1365-2427. 2012.02742.x.

Wallace, J.B., Eggert, S.L., Meyer, J.L., and Webster, J.R., 1997, Multiple trophic levels of a forest stream linked to terrestrial litter inputs: Science, v. 277, p. 102-104. doi:10.1126/science.277.5322.102.

Webster, J.R., Benfield, E.F., Ehrman, T.P., Schaeffer, M.A., Tank, J.L., Hutchens, J.J., and D'Angelo, D.J., 1999, What happens to allochthonous material that falls into streams? A synthesis of new and published information from Coweeta: Freshwater Biology, v. 41, p. 687-705. doi:10.1046/j.1365-2427.1999.00409.x.

Weider, R.K., and Lang, G.E., 1982, A critique of the analytical methods used in examining decomposition data obtained from litter bags: Ecology, v. 63, p. 1636-1642. doi:10.2307/1940104.

Zar, J.H., 1996, Biostatistical Analysis, third edition: Upper Saddle River, New Jersey, Prentice Hall, 662 p. 